\title{
Pollution threatens water quality in the Central Marshes of Southern Iraq
}

\author{
Nadheer A. Fazaa ${ }^{* 1,2}$ (iD) Jonathon C. Dunn ${ }^{2} \quad$ Mark J. Whittingham $^{2}$
}

\author{
${ }^{1}$ Department of Biology, College of Sciences for Women, University of Baghdad, Jadria, Baghdad, Iraq. \\ ${ }^{2}$ School of Natural and Environmental Sciences, Newcastle University, Newcastle Upon Tyne, UK. \\ *Corresponding author: nadheerabood@gmail.com \\ E-mails: jon.donn@newcastle.ac.uk, mark.whittingham@newcastle.ac.uk
}

Received 22/8/2020, Accepted 15/9/2021, Published 20/12/2021

This work is licensed under a Creative Commons Attribution 4.0 International License.

\begin{abstract}
:
Water pollution is an issue that can be exacerbated by drought as increased concentrations of unwanted substances are a consequence of lower water levels. Polluted water that flows into natural marshlands leads to the deposition of pollutants in the interior of the marsh. Here we present evidence that the interior of the Central Marsh (CM) in southern Iraq suffers from higher levels of pollution than areas closer to the source of water entering the marsh (the Euphrates River). A $1.7 \mathrm{~m}$ embankment that halts the flow of the Euphrates is only infrequently breached and so the CM is effectively the terminal destination of the waters (and their associated pollutants and agricultural waste) flowing from the West of Iraq.
\end{abstract}

A range of water quality metrics were measured where the Euphrates enters the $\mathrm{CM}$ and at increasing distances into the interior of the $\mathrm{CM}$. The following measures were taken: $\mathrm{NO}_{2}, \mathrm{NO} 3, \mathrm{PO} 4$, Salinity, Major ions, and Heavy Metals $(\mathrm{Cu}, \mathrm{Ni}, \mathrm{Pb}, \mathrm{Cd}, \mathrm{Zn})$. The area of study was divided into four horizontal zones (the river and three zones inside the marsh) and eight field surveys were carried out from November 2013 to June 2014 to collect water samples by using a transect line methodology.

Salinity and major ions $(\mathrm{Na}, \mathrm{K}, \mathrm{Cl}, \mathrm{Ca}$, and $\mathrm{Mg}$ ) were significantly higher inside the marsh compared with levels in the river water immediately before it entered the CM. These findings indicate the increased risk of these pollutants to humans and wildlife living in and using the CM. This issue requires urgent attention, especially to the status of the CM as a World Heritage site (for the ecosystem services provided to local people) as an Important Biodiversity Area. The reported declines in water quantity in the Euphrates over recent decades will likely further exacerbate the problems we report.

Keywords: Central Marsh, Mesopotamian Marshlands, water Quality, water salinity.

\section{Introduction:}

Iraq's Central Marsh (CM) is one of the most important wetlands/ecosystems in the south of Iraq 1,2. The CM is an Important Birds Area (IBA) ${ }^{3}$, Key Biodiversity Area $(\mathrm{KBA})^{4}$, and the first national park in Iraq ${ }^{5,6}$ (Fig.1). The site provides many ecosystem services to humans living in the $\mathrm{CM}$, which underwent a rapid increase from 41,000 in 2005 to 152,844 in $2015^{7}$. Among those ecosystem services provided by the $\mathrm{CM}$, water quality is of particular importance, both for people and for their environment. The $\mathrm{CM}$ was historically provided with water from the Tigress and Euphrates rivers, which are the main two rivers in the Mesopotamian basin $^{8}$. The CM was desiccated by the government in the 1990s and re-flooded in $2003^{2}$. As a consequence of the restoration, the hydrology of the $\mathrm{CM}$ changed, so that ever since it has depended on inflow from the Euphrates River alone ${ }^{9}$. The Euphrates River collects $100 \%$ of its water from Turkey and Syria, respectively, in the upstream region, with no tributary contributing to the Euphrates inside Iraq ${ }^{10}$.

The natural flow inside Iraq reached 60 billion cubic meters (BCMs) in 1963 before the construction of dams in upstream countries, while it decreased significantly after dam construction and especially after implementation of the GAP project in Turkey (Güneydoğu Anadolu Projesi) that started in $1990^{11}$ [e.g. the Euphrates flow was 30.6 BCM in the upstream (border of Iraq) while reduced 
dramatically in the present to $\left.4 \mathrm{BCM}^{12}\right]$. The Euphrates' water in the upstream provinces inside Iraq is used for agricultural irrigation and municipal water supply, with sewage water dumped directly into the river in some upstream provinces. The Euphrates played an essential role in diluting pollution that came from agriculture and irrigation and other upstream human activities before $1990^{13}$. Following the significant decrease in water volume flowing through the Euphrates with a combined significant increase in human population and thus municipal discharge of sewage, the capacity of the Euphrates to dilute pollutants was severely impaired $^{14}$.

Despite the considerable efforts that were spent by the Iraqi government and various civil societies post-2004, it was not possible to restore the CM to $100 \%$ of its original pre-desiccation area as a direct consequence of the water scarcity in the Euphrates ${ }^{1,15}$. As a result, the local authority in Chibayish City, the Iraqi Ministry of Water Resources, the Iraqi Ministry of Environment and other stakeholders were decided to implement several actions to help reduce the impact of water scarcity in the Euphrates on the restoration of the CM. The actions were: 1) to declare 141, 615 ha of the $\mathrm{CM}$ as a national park in $2013^{5,6}, 2$ ) to construct nine gates with the capacity to control up to $1.7 \mathrm{~m}$ of water between the Euphrates and the national park in $2006^{9}$; and 3) to construct a soil embankment in the Euphrates in 2010 between Chibayish city in Thi-Qar province and Modina city in Basra province ${ }^{7}$. The establishment of the embankment was one of the most important actions for the restoration of the $\mathrm{CM}$ after the severe situation that faced the area due to water scarcity in the Euphrates River. This action helped to provide sufficient water volume to reflood the marsh area.

The impact of establishing the soil embankment on the CM's local people and ecosystem services has not been examined by the Iraqi government or scientists. Previous studies have noted that there are now significantly raised salinity levels within the $\mathrm{CM}^{15,16}$, but there has not been consensus on the cause of this change. Due to a lack of information about the impact of the soil embankment and water scarcity on the CM, this study aims to provide baseline data on water quality within the CM postconstruction of the soil embankment. This will also allow an evaluation of the role of the $\mathrm{CM}$ in cleaning water that comes from the Euphrates River. Thus, the study can help both policy makers and local people have a better understanding of the impact of water scarcity in the Euphrates River and its consequences on both people and the wildlife in the CM.

The present study is designed to compare water quality at varying distances along water courses that flow from the Euphrates River into the CM. We predicted that the greater the distance water flows from the entry of the Euphrates into the CM water, the greater the quality would decline. This is because there is no flow of water through the CM and so it acts as a sink for pollution the greater the distance the water travels into the marsh.

\section{Methods:}

\section{Field Survey: sampling protocol}

Eight surveys were carried out in the $\mathrm{CM}$ once a month from November 2013 to June 2014. Water samples were first collected from zone a (the Euphrates River) in the south in the morning and were sequentially collected along transects in zones b, c, and d (Fig.2) Water sampling sites are shown in Fig 2; five sites were chosen in transect one (we merged data from sites $\mathrm{d}$ and e and consider it as one site in transect 1 , using the mean values), and four sites were chosen in transects two and three (in total 96 samples were collected during 8 months). Two kinds of bottle samples (glass and plastic) were used to sample one litre of water/site. Hanna portable instruments (HI 9811-5) were used to measure $\mathrm{pH}, \mathrm{EC}$, and TDS of water directly in the field. Data on monthly water levels for the Euphrates River were supplied by the Iraqi Ministry of Water Resources (Chibayish branch) (Annexes, Table 10.).

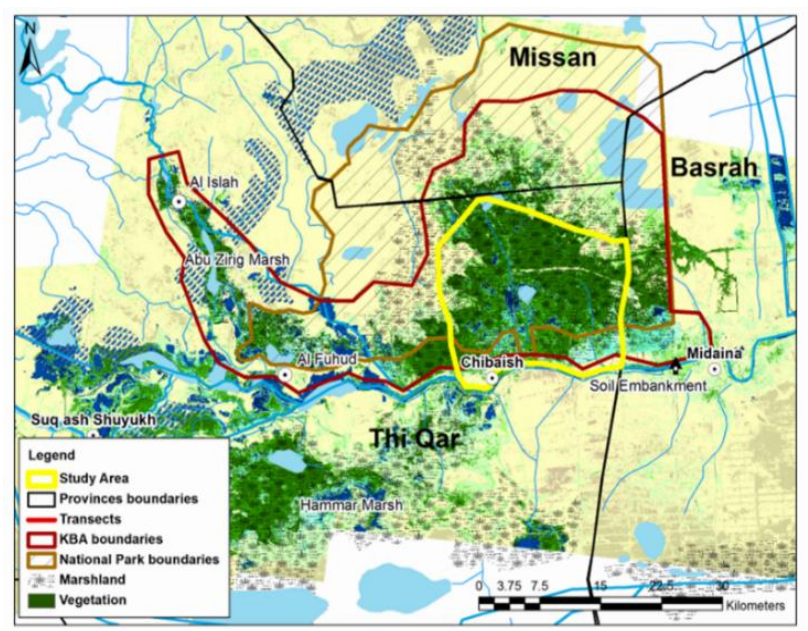

Figure 1. The Central Marsh in southern Iraq. Yellow line is the study area, the red line shows the Key Biodiversity Area (KBA) boundaries, and the brown line shows the boundary of the national park area. 


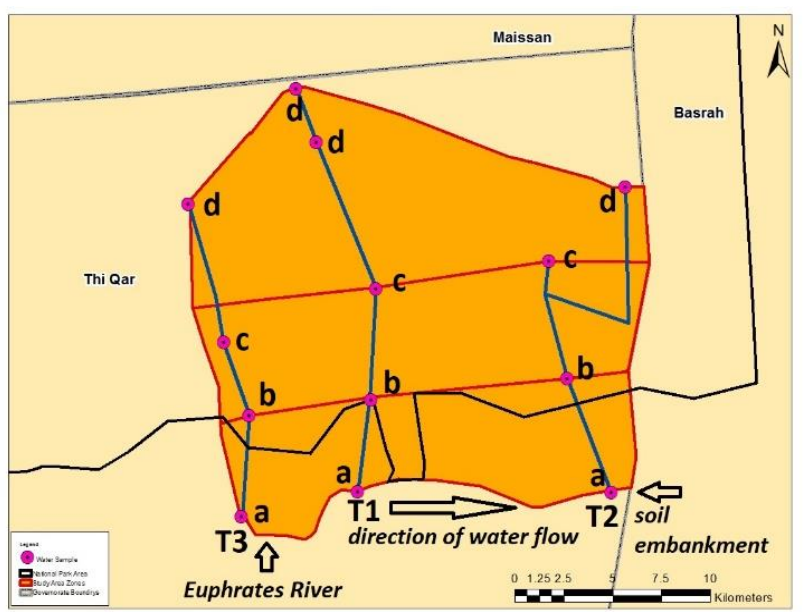

Figure 2. Study area showing water sampling sites (shown as pink dots) with transects numbered 1-3; there are four zones at varying distances from the Euphrates River (Zone a immediately adjoining the Euphrates River) and zones b, c, and $d$ at progressively further distances from the Euphrates River.

\section{Laboratory analysis}

Water samples were analysed in the water laboratory of the Environmental Centre in the University of Technology in Baghdad using the standard methods recommended by the American Public Health Association ${ }^{17}$. Samples were sent from the CM to the laboratory in Baghdad within an ice box. Eighteen parameters were analysed in the lab to measure concentrations of water salinity, nutrients, anions, and heavy metals in samples from the Euphrates River and the Central Marsh. The parameters were: Electrical Conductivity (EC), salinity, Total Dissolved Solid (TDS), Total Suspended Solids (TSS), Total Hardness; and concentrations of $\mathrm{NO}_{2}, \mathrm{NO}_{3}, \mathrm{PO}_{4}, \mathrm{Na}, \mathrm{K}, \mathrm{Cl}, \mathrm{Ca}$, $\mathrm{Mg}, \mathrm{Cu}, \mathrm{Ni}, \mathrm{Pb}, \mathrm{Cd}$, and $\mathrm{Zn}$. These parameters were chosen because they encompassed a range of physical and chemical indicators of water quality. For example, heavy metals such as $\mathrm{Zn}$ can have negative impacts on both humans and wildlife throughout the food web.

\section{Statistical analyses}

ANOVAs were performed to test the influence of zone, transect, and month of sampling, and their interactions with the physical and chemical water parameters. Model residual plots were examined to check for assumptions of normality and homogeneity of variance. All models satisfied these assumptions. All the analyses were conducted using $\mathrm{R}$ programme version 3.5.0. The $\mathrm{pH}$ values in the field were analysed by using MATLAB programme.

\section{Results: \\ Field Survey Results}

Results from the field surveys for $\mathrm{pH}, \mathrm{EC}$, and TDS (Fig 4) indicated differences between the Euphrates River zone and marsh zones (b, c, and d) (values, statistical significances, and the SE bars of these differences are shown in Fig. 4, and in the Annexes - Table 1). Relative values of $\mathrm{pH}$ in the River zone (zone A) were higher than $\mathrm{pH}$ in the marsh (zones b, c, and d) although absolute levels varied between seasons (see Fig. 3). December had the highest value of $\mathrm{pH}$ and June had the lowest and transect two had the highest values of $\mathrm{pH}$ compared with transect one and three (Fig. 3, Fig. 4, and Table 1 in the Annexes). 


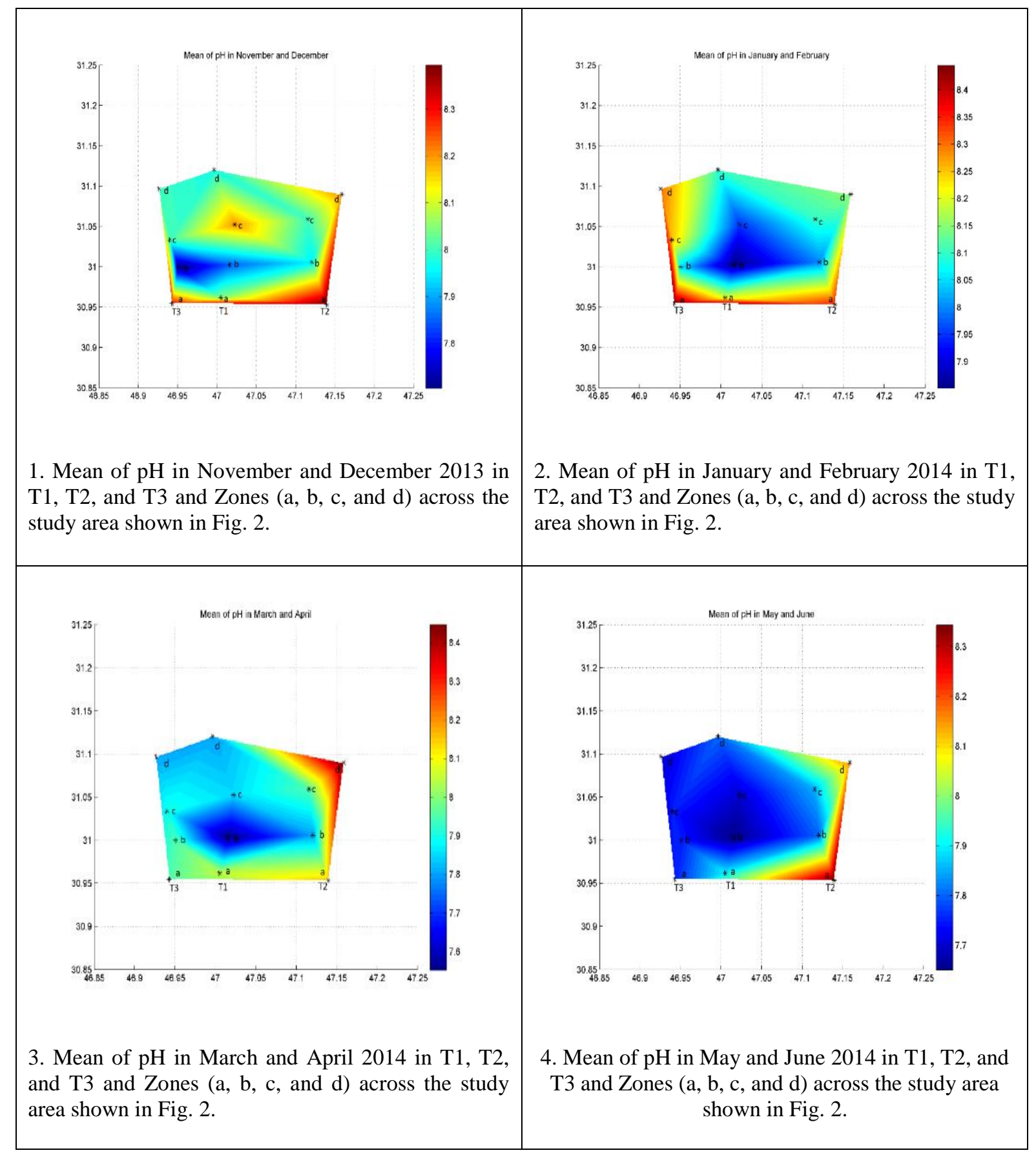

Figure 3. Mean of pH in the area of study from November 2013 to June 2014 across different months (produced using MATLAB programme). 

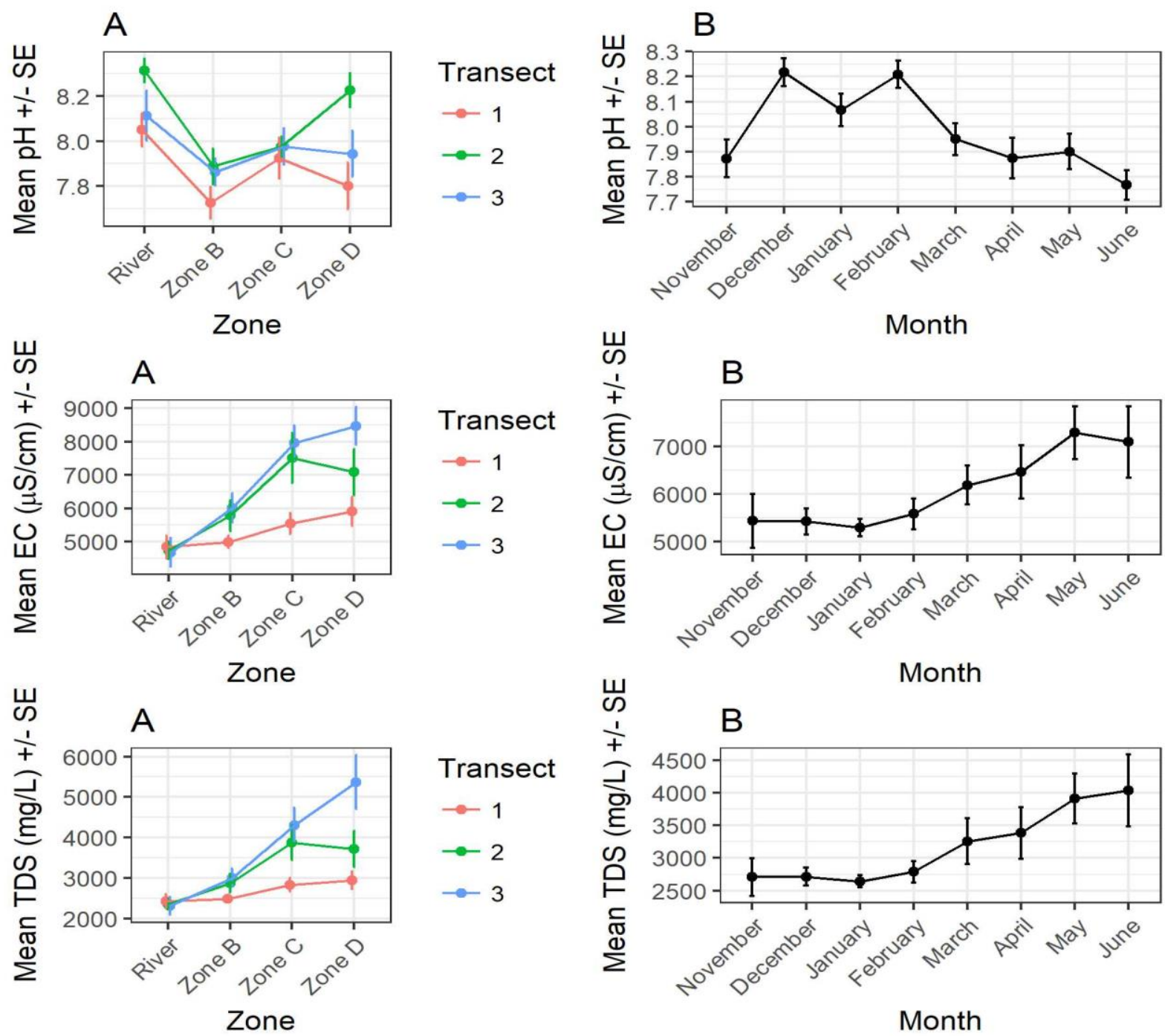

Figure 4. Field measurements of mean $\pm \mathrm{SE}$ of $\mathrm{pH}, \mathrm{EC}$, and TDS in the $\mathrm{CM}$ for $\mathrm{A}$ ) zones and transects; B) months from November 2013 to June 2014. $\mathrm{N}=96$ samples across entire field seasons.

\section{Laboratory Analysis Results:}

Results of the laboratory analysis for 18 parameters (EC, salinity, TSS, TDS, turbidity, $\mathrm{NO}_{2}, \mathrm{NO}_{3}, \mathrm{PO}_{4}$, $\mathrm{Na}, \mathrm{K}, \mathrm{Ca}, \mathrm{Mg}, \mathrm{Cl}, \mathrm{Cu}, \mathrm{Ni}, \mathrm{Pb}, \mathrm{Cd}$, and $\mathrm{Zn}$ ) indicated variation between river zone (zone $\mathrm{A}$ ) and marsh zones (zones B, C, and D). We divided the results into four groups as follows: group 1 (EC, salinity, TSS, TDS, and turbidity) to evaluate and give an overall assessment of salinity and turbidity in the Euphrates River and the CM; group $2\left(\mathrm{NO}_{2}\right.$, $\mathrm{NO}_{3}$, and $\mathrm{PO}_{4}$ ) to evaluate nutrients in the river and the $\mathrm{CM}$; group $3(\mathrm{Na}, \mathrm{K}, \mathrm{Ca}, \mathrm{Mg}$, and $\mathrm{Cl})$ to evaluate major ions in the water; and group $4(\mathrm{Cu}$, $\mathrm{Ni}, \mathrm{Pb}, \mathrm{CD}$, and $\mathrm{Zn}$ ) to evaluate heavy metals in the water. Observed values, the statistical significances between treatments, and the SE bars of the differences are show in Figs. 5-8 and Tables 2-9 in the Annexes.

Group 1: Salinity, EC, TSS, TDS, and Turbidity. The results indicated that river values of EC, salinity, TSS, TDS, and turbidity were less than values within the CM (Fig. 5- A). Inside the $\mathrm{CM}$ the
EC and salinity values were higher in zone $\mathrm{D}$, while the TDS and turbidity values were higher in zone $\mathrm{C}$. Values of all the indicators in this group were higher in transect 3 compared with transects 1 and 2 (Fig.5- A). Values for June were consistently higher for all indicators in this group (Fig. 5- B). Statistically significant interactions are indicated in the Fig. 5 and in the Annexes (Tables 2 and 3) highlighting differences (and lack of differences) between space (zone and transect) and time (month).

Group 2: $\mathrm{NO}_{2}, \mathrm{NO}_{3}$, and $\mathrm{PO}_{4}$

There were no significant differences in nutrient concentrations $\left(\mathrm{NO}_{2}, \mathrm{NO}_{3}\right.$, and $\left.\mathrm{PO}_{4}\right)$ between the Euphrates River and the CM's zones and transects (Fig. 6-A shows the large standard errors for samples in different zones nearly all overlapping with each other). However, there were clear differences between monthly means values of the $\mathrm{NO}_{2}$ and $\mathrm{NO}_{3}$ (Fig. 6-B). Statistically significant interactions are indicated in Fig. 6 and in Tables 4 and 5 (see Annexes). 
Group 3: Major Ions ( $\mathrm{Na}, \mathrm{K}, \mathrm{Ca}, \mathrm{Mg}$, and $\mathrm{Cl}$ )

Analysis of major anions ( $\mathrm{Na}, \mathrm{K}, \mathrm{Cl}, \mathrm{Ca}$, and $\mathrm{Mg}$ ) indicated that the concentrations in the Euphrates River (zone A) were less than the CM. Zone D and transect 3 had the highest means compared with zones $\mathrm{B}$ and $\mathrm{C}$, and transects 1 and 2 (Fig. 7 ). Statistically significant interactions are indicated in Fig. 7 and in the annexes (tables 6 and 7).

Group 4: Heavy Metals ( $\mathrm{Cu}, \mathrm{Ni}, \mathrm{Pb}, \mathrm{CD}$, and $\mathrm{Zn}$ ) Analysis of variance indicated that the main effects of zone, transect, and month were significant for all heavy metals and their interactions $(\mathrm{Cu}, \mathrm{Ni}, \mathrm{Pb}, \mathrm{Cd}$,
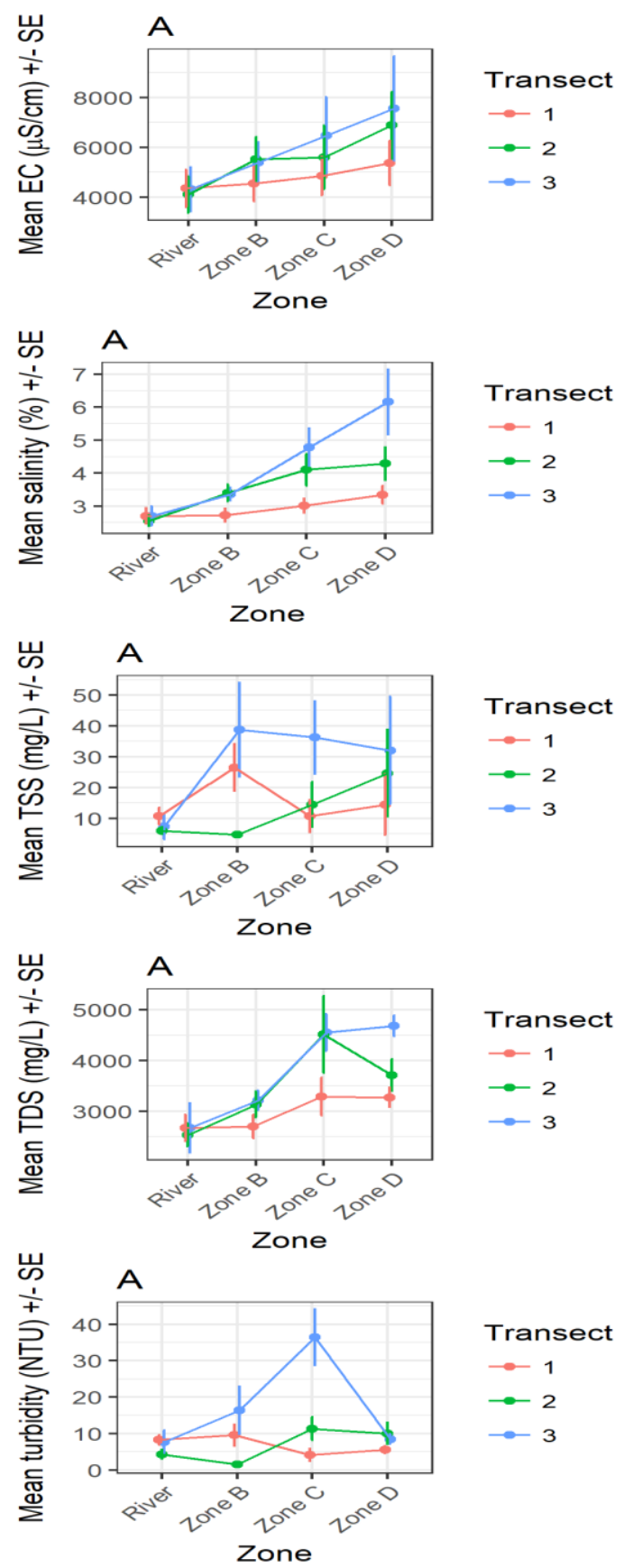

and $\mathrm{Zn}$ ) (Fig. $8 \mathrm{~A}$ and B). The exception was the interaction between zone and transect, which were not significant for all metals. Zone and month interactions were also not significant for $\mathrm{Zn}$. In general, the mean \pm SE for all metals was significantly higher in the marsh compared to the river. Within the marsh, zone $\mathrm{D}$ has the highest metal content. On the other hand, metal contents were significantly higher in transect 3 compared to transects 1 and 2. Statistically significant values and interactions are indicated in Fig. 8 and in the annexes (tables 8 and 9).
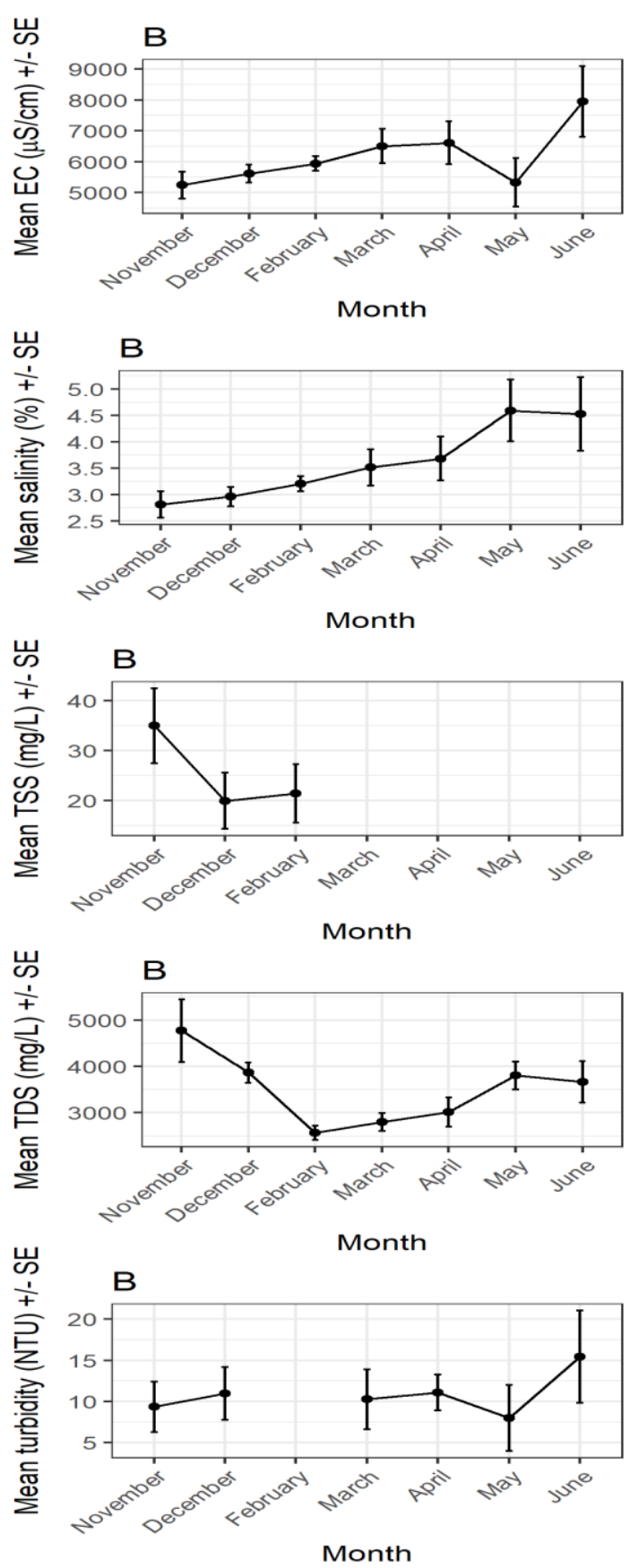

Figure 5. Laboratory mean \pm SE (between-subjects) EC values $\mu \mathrm{S} / \mathrm{cm}$, salinity values in $\%$, TSS values in mg/L, TDS values in $\mathrm{mg} / \mathrm{L}$, and turbidity in NTU in the Euphrates River and CM for A) zones and transects; B) months (from November 2013 to June 2014. 
$\mathrm{N}=96$ samples across entire study period.) $\quad$ EC values $\mu \mathrm{S} / \mathbf{c m}$ : A two-way ANOVA showed that there was a statistically significant interaction between transect and month $\left(\mathrm{F}_{7,49}=3.70, \mathrm{p}<0.001\right)$ and zone and month $\left(\mathrm{F}_{21,49}=3.70, \mathrm{p}<0.001\right)$ but not transect and zone $\left(\mathrm{F}_{3,49}=1.80, \mathrm{p}=0.20\right)$. salinity values in \%: A two-way ANOVA showed that there was a statistically significant interaction between transect and month $\left(\mathrm{F}_{7,49}=3.90, \mathrm{p}<0.001\right)$ and zone and month $\left(\mathrm{F}_{21,49}=6.10, \mathrm{p}<0.001\right)$ and transect and zone $\left(\mathrm{F}_{3,49}=16.50, \mathrm{p}<0.001\right)$. TSS values in mg/L: A two-way ANOVA showed that there was no statistically significant interaction between transect and month $\left(\mathrm{F}_{3,21}=1.60, \mathrm{p}=0.20\right)$ and zone and month $\left(\mathrm{F}_{9,21}=0.50, \mathrm{p}=0.90\right)$ and transect and zone $\left(\mathrm{F}_{3,21}=0.80, \mathrm{p}=0.50\right)$. TDS values in $\mathbf{m g} / \mathbf{L}$ : A two-way ANOVA showed that there was not a statistically significant interaction between transect and month $\left(\mathrm{F}_{7,49}=3.70, \mathrm{p}=0.80\right)$ but there was between zone and month $\left(\mathrm{F}_{21,49}=3.70\right.$, $\mathrm{p}<0.001)$ and not transect and zone $\left(\mathrm{F}_{3,49}=4.50\right.$, $\mathrm{p}<0.001)$. Turbidity values in NTU: A two-way ANOVA showed that there was not a statistically significant interaction between transect and month $\left(\mathrm{F}_{6,42}=1.80, \quad \mathrm{p}=0.10\right)$ and zone and month $\left(\mathrm{F}_{18,42}=0.50, \mathrm{p}=0.90\right)$ but there was between transect and zone $\left(\mathrm{F}_{3,42}=7.40, \mathrm{p}<0.001\right)$.
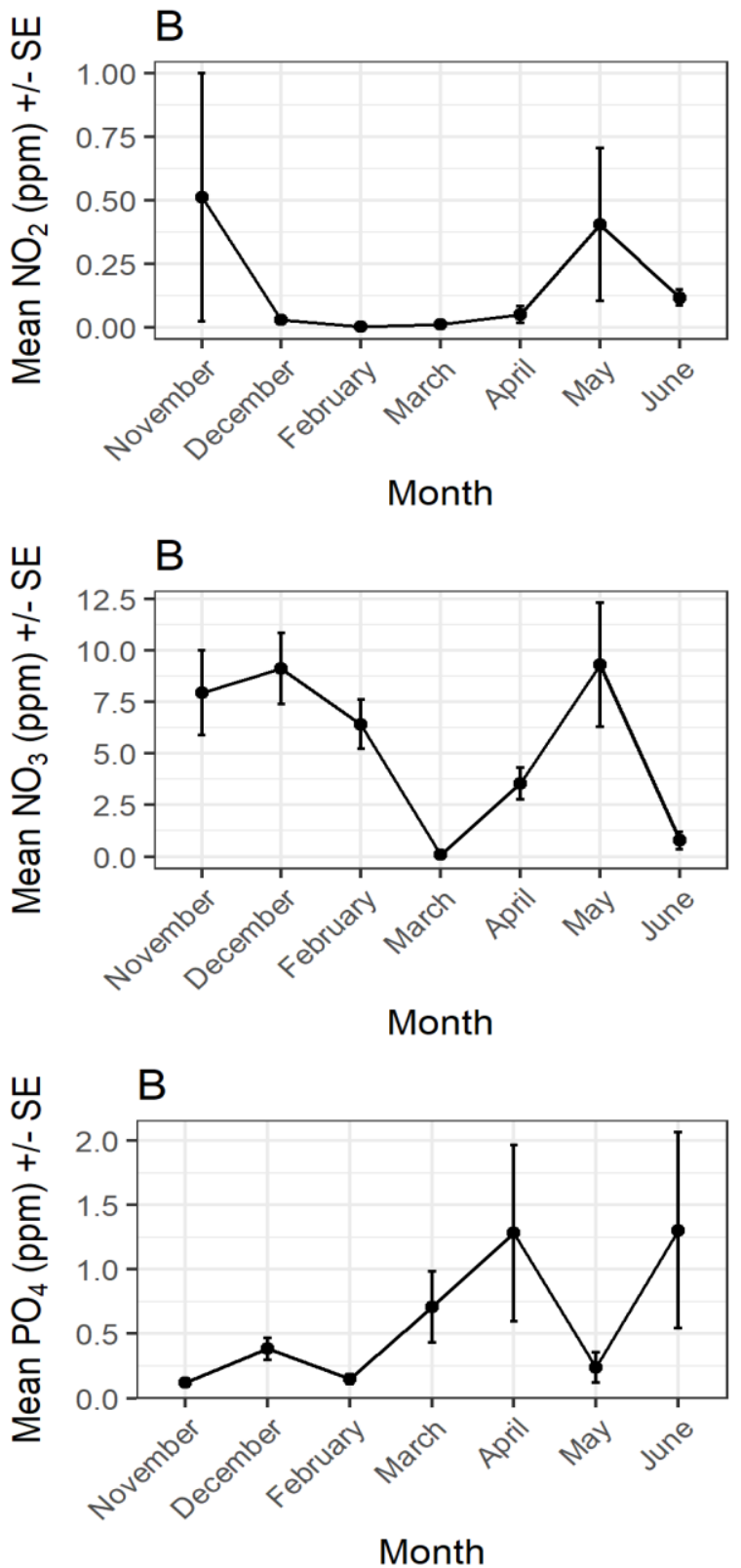

Figure 6. Laboratory mean \pm SE (between-subjects) NO2 values in ppm, NO3 values in ppm, and PO4 values in ppm in the Euphrates River and CM for A) zones and transects; B) months from November 2013 to June 2014. 
$\mathrm{N}=96$ samples across entire study period. NO2 values: A two-way ANOVA showed that there was no statistically significant interaction between transect and month $\left(\mathrm{F}_{7,49}=2.00, \mathrm{p}=0.10\right)$ and zone and month $\left(\mathrm{F}_{21,49}=1.60, \mathrm{p}=0.10\right)$ and transect and zone $\left(\mathrm{F}_{3,49}=2.00, \mathrm{p}=0.10\right)$. NO3 values: A two-way ANOVA showed that there was not a statistically significant interaction between transect and month
$\left(\mathrm{F}_{7.49}=1.10, \quad \mathrm{p}=0.40\right)$ and zone and transect $\left(F_{3,49}=2.00, p<0.01\right)$ but there was between zone and month $\left(\mathrm{F}_{21,49}=2.90, \mathrm{p}<0.001\right)$. PO4 values: A twoway ANOVA showed that there was not a statistically significant interaction between transect and month $\left(\mathrm{F}_{7,49}=3.70, \mathrm{p}=0.60\right)$ and zone and month $\left(\mathrm{F}_{21,49}=1.20, \quad \mathrm{p}=0.30\right)$ and transect and zone $\left(\mathrm{F}_{3,49}=1.50\right.$, $\mathrm{p}=0.20)$.
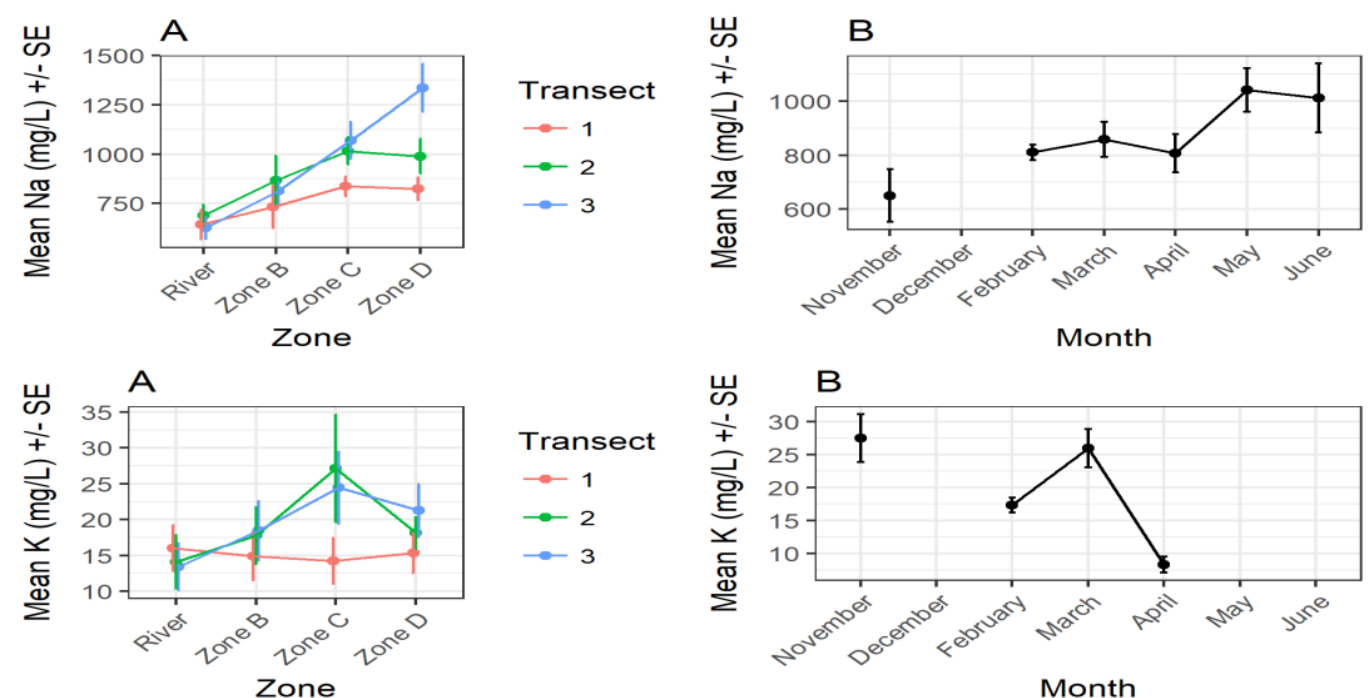

Transect

$\because 1$

$\rightarrow 2$

$\rightarrow 3$
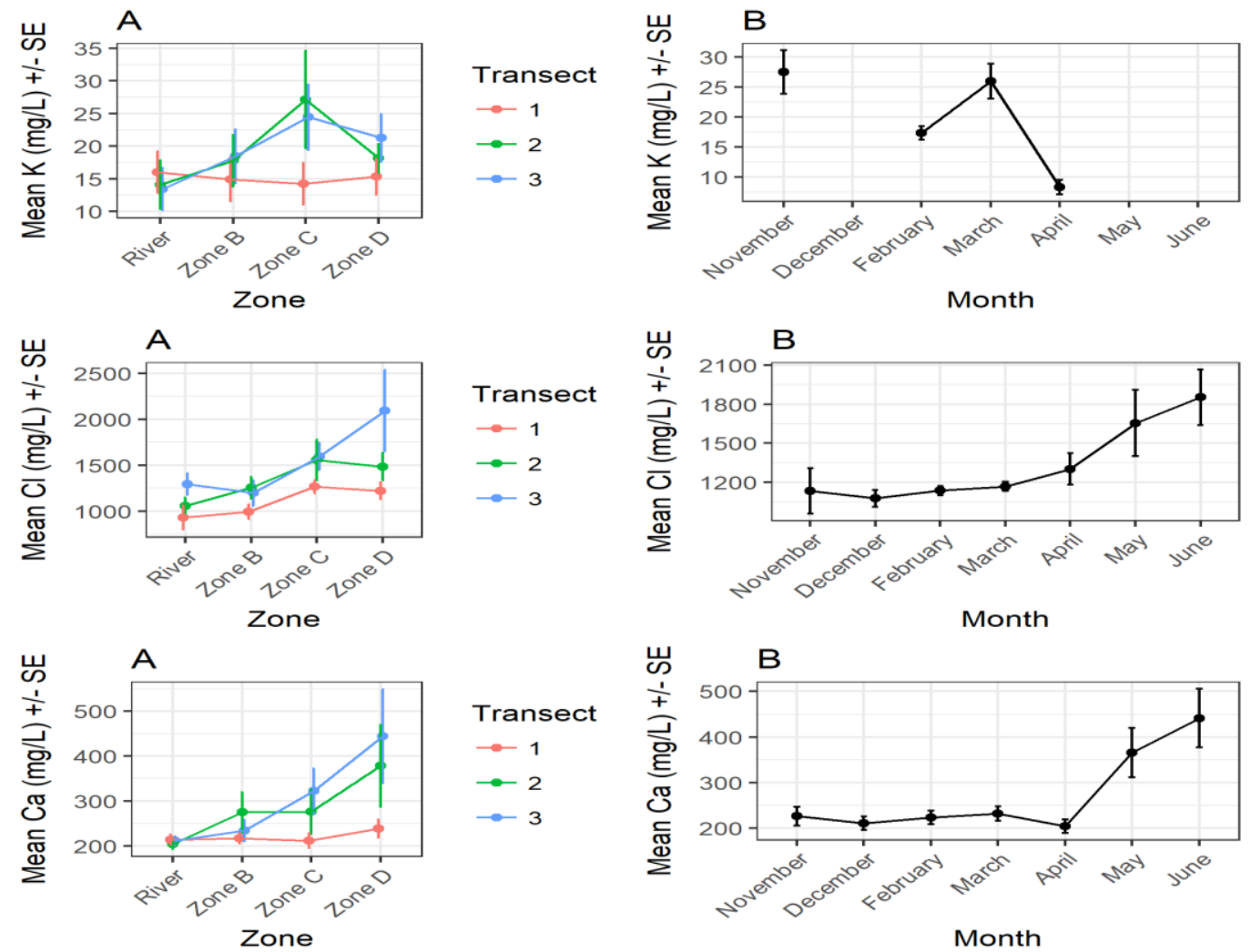

Transect

$\because 1$

$\rightarrow 2$

$\rightarrow 3$

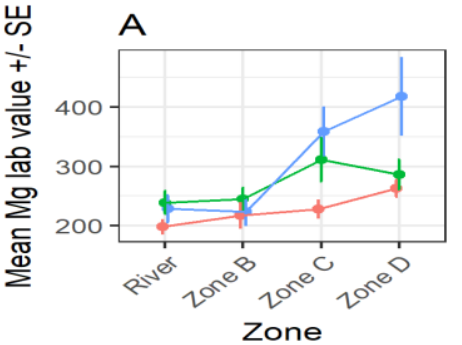

Transect

$\because 1$

$\because 2$

$-3$

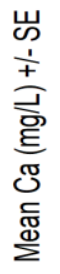
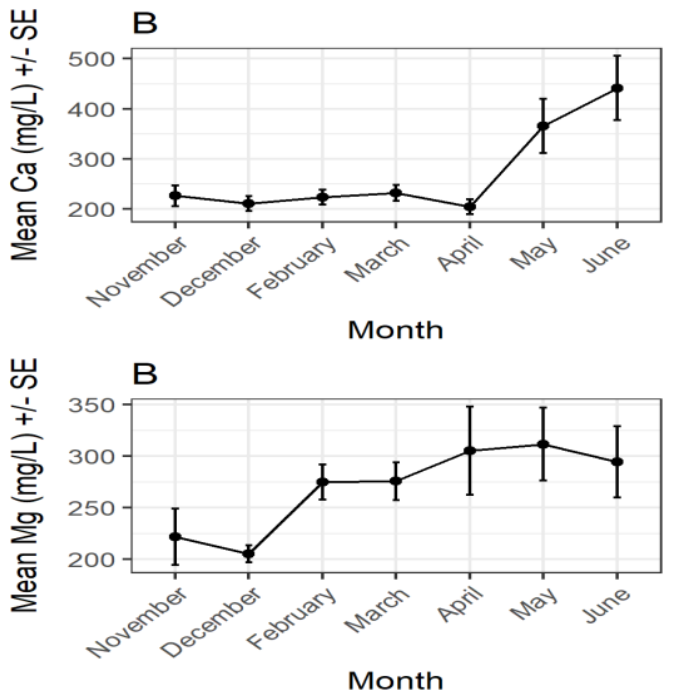

Figure 7. Laboratory mean $\pm \mathrm{SE}$ (between-subjects) $\mathrm{Na}$ in $\mathrm{mg} / \mathrm{L}, \mathrm{K}$ in mg/L, $\mathrm{Cl}$ in mg/L, Ca in mg/L, and $\mathrm{Mg}$ in $\mathrm{mg} / \mathrm{L}$. in the Euphrates River and $\mathrm{CM}$ for $\mathrm{A}$ ) zone and transects; B) months from November 2013 to June 2014.

$\mathrm{N}=77$ samples across entire study period. $\mathbf{N a}$ in mg/L: A two-way ANOVA showed that there was not a statistically significant interaction between transect and month $\left(\mathrm{F}_{6,39}=0.90, \mathrm{p}=0.50\right)$ but there 
was between zone and month $\left(\mathrm{F}_{18,39}=2.20, \mathrm{p}=0.02\right)$ and transect and zone $\left(\mathrm{F}_{18,39}=1.8, \mathrm{p}=0.02\right)$. Cl: $\mathrm{A}$ two-way ANOVA showed that there was a statistically significant interaction between transect and month $\left(\mathrm{F}_{7,49}=5.80, \mathrm{p}<0.001\right)$ and zone and month $\left(\mathrm{F}_{21,49}=3.20, \mathrm{p}<0.001\right)$ and transect and zone $\left(\mathrm{F}_{3,49}=8.10, \mathrm{p}=0.01\right)$. Mg, A two-way ANOVA showed that there was a statistically significant interaction between transect and month $\left(\mathrm{F}_{7,49}=2.40\right.$, $\mathrm{p}=0.03)$ and zone and transect $\left(\mathrm{F}_{3,49}=4.90, \mathrm{p}<0.001\right)$ but not month and zone $\left(\mathrm{F}_{21,49}=1.60, \mathrm{p}=0.07\right)$. K, A
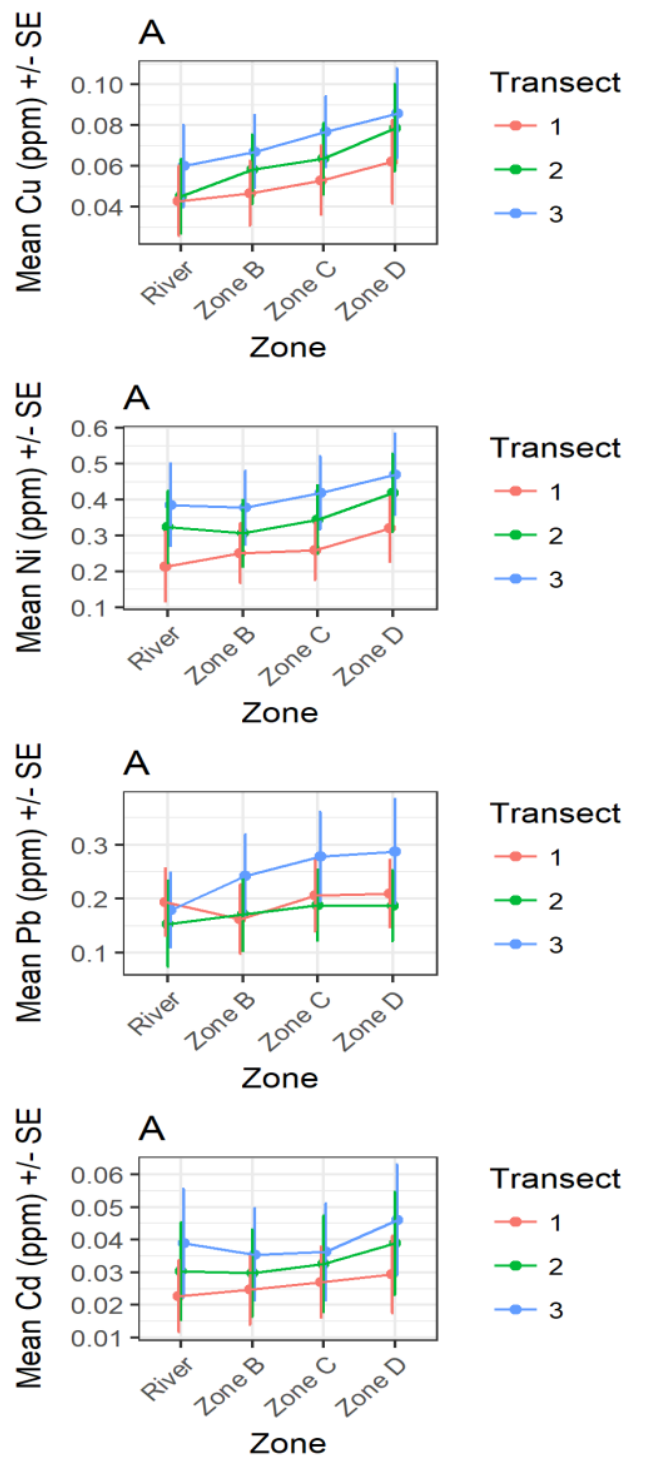

Transect

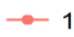

$--2$

$\rightarrow 3$

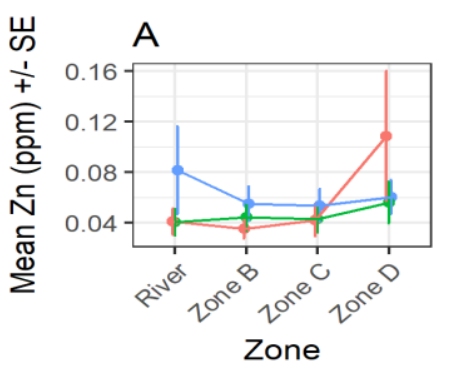

Transect

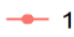

$\rightarrow 2$

$\rightarrow-2$
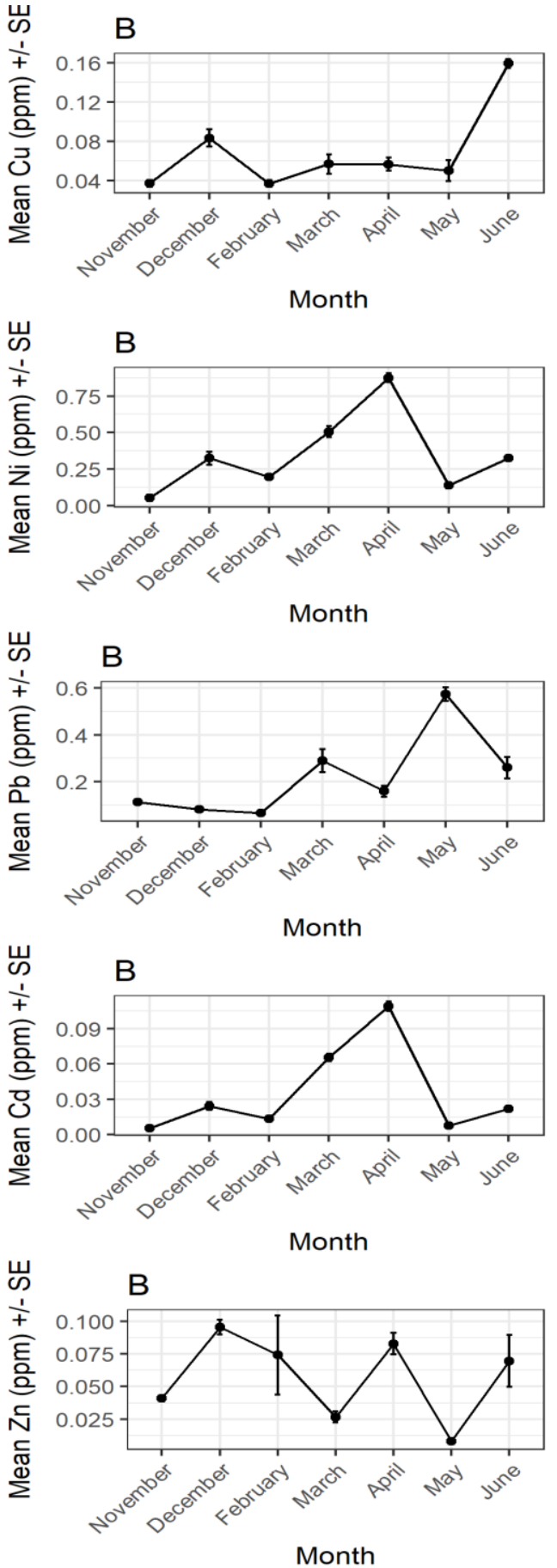

Figure 8. Laboratory mean $\pm \mathrm{SE}$ (between-subjects) $\mathrm{Cu}$ in ppm. $\mathrm{Ni}$ in ppm, $\mathrm{Pb}$ in ppm, $\mathrm{Cd}$ in ppm, and $\mathrm{Zn}$ in ppm in the Euphrates River and CM for A) zone and transects; B) from November 2013 to June 
$\mathrm{N}=96$ samples across entire study period. $\mathrm{Cu}$ in ppm: A two-way ANOVA showed that there was a statistically significant interaction between transect and month $\left(\mathrm{F}_{7,49}=6.90, \mathrm{p}<0.001\right)$ but not zone and month $\left(\mathrm{F}_{21,49}=1.00, \mathrm{p}=0.50\right)$ or transect and zone $\left(\mathrm{F}_{3,49}=0.20, \mathrm{p}=0.90\right)$. Ni in ppm: A two-way ANOVA showed that there was a statistically significant interaction between transect and month $\left(\mathrm{F}_{7,49}=9.90, \quad \mathrm{p}<0.001\right)$ and zone and month $\left(\mathrm{F}_{21,49}=4.90, \mathrm{p}<0.001\right)$ but not transect and zone $\left(\mathrm{F}_{3,49}=0.80, \mathrm{p}=0.50\right)$. $\mathbf{P b}$ in $\mathbf{p p m :} \mathrm{A}$ two-way ANOVA showed that there was a statistically significant interaction between transect and month $\left(\mathrm{F}_{7,49}=2.50, \mathrm{p}=0.02\right)$ but not zone and month $\left(\mathrm{F}_{21,49}=1.20, \quad \mathrm{p}=0.03\right)$ or transect and zone $\left(\mathrm{F}_{3,49}=1.30, \mathrm{p}=0.30\right)$. Cd in ppm: A two-way ANOVA showed that there was a statistically significant interaction between transect and month $\left(\mathrm{F}_{7,49}=19.30, \mathrm{p}<0.001\right)$ and zone and month $\left(\mathrm{F}_{21,49}=3.70, \mathrm{p}<0.001\right)$ but not transect and zone $\left(\mathrm{F}_{3,49}=0.90, \mathrm{p}=0.40\right) . \quad \mathrm{Zn}$ in $\mathbf{p p m :} \mathrm{A}$ two-way ANOVA showed that there was not a statistically significant interaction between transect and month $\left(\mathrm{F}_{7,49}=1.70, \quad \mathrm{p}=0.10\right)$ and zone and month $\left(\mathrm{F}_{21,49}=1.30, \mathrm{p}=0.20\right)$ but there was for transect and zone $\left(\mathrm{F}_{3,49}=1.80, \mathrm{p}=0.20\right)$.

\section{Discussion:}

Salinity in the Mesopotamian Rivers (Tigress and Euphrates) increased significantly from 1970 to 2008 as a result of the huge reduction of the water discharged in both rivers (from $84.6 \times 10^{9} \mathrm{~m}^{3}$ to 13.8 $\mathrm{x} 10^{9} \mathrm{~m}^{3}$ respectively) ${ }^{18}$. Sequentially, salinity of the Iraqi marshlands has increased dramatically (from 0.4 psu to 2.5 psu in 1980 , and then by another 1.1 psu between 2005 and 2008 (to 3.6 psu) ${ }^{19}$ and the water has changed from fresh to brackish water ${ }^{1}$. Salinity in the marshlands is affected by two factors: water quantity (historical peak of water levels is from April - June and historical trough of water levels is from September - November ${ }^{19}$; and evaporation (high evaporation and low rainfall occurs in the Summer) ${ }^{15}$.

Dam construction upstream of the rivers, pollution, increasing agricultural activities, evaporation, and the tidal effect of the Shatt Al Arab in Basra province are among the reported reasons for the increased salinity levels in the Iraqi southern marshlands ${ }^{9,6}$. Our results indicated that salinity concentrations inside the CM (zones $\mathrm{C}, \mathrm{B}$, and $\mathrm{D}$ ) are significantly higher than the Euphrates River (zone A), which is the main source of water into the $\mathrm{CM}$, and it is higher in the summer compared to the winter. Moreover, the concentration of salinity was higher when the water was sampled further from the river (e.g. zone D vs. zones $\mathrm{B}$ and $\mathrm{C}$ ). Some previous studies indicated that $\mathrm{CM}$ could be influenced by the marine tide of the Shatt $\mathrm{Al}$

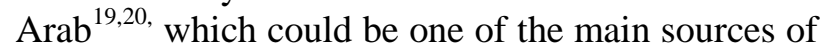
salinity in the marsh. Our results showed that there are still high levels of salinity within the CM but they cannot be explained (at least wholly) by the marine tide as the existence of the newly constructed soil embankment between Chibayish City and Modina City largely prevents water from re-entering the CM in this way (see Figs. 1 and 2).

Dividing the area of study into three transects helped to confirm our findings: The Euphrates water comes from the west and then crosses the CM towards Chibayish City in the east. Our results clearly indicated that transect three (located immediately before Chibayish city) had the highest concentration of water salinity compared with transect one (located in the middle of Chibayish city) and transect two (located after Chibayish city and close to the soil embankment). If the marine tide was a major source of salinity, we would have expected the opposite pattern to be true. Analysis of major ions could provide additional evidence of increases in the salinity concentration. Major ions concentrations in the $\mathrm{CM}$ increased significantly from 2005 to $2008^{19}$, with the same study indicating that chloride ion concentrations were higher and fluctuated more than the calcium and magnesium ions, especially in the summer. Our results have indicated the same findings, in which major ions concentrations in the CM were higher than in the Euphrates River.

Heavy metals can occur naturally in the marsh water. Increasing metal concentrations could cause an acute or chronic toxic problem on the ecosystem structure, wildlife, and food chain, which can affect negatively on humans and the health, diversity, and distribution of other species that use the aquatic ecosystem $^{21}$. Historically the Mesopotamian marshlands used to be an excellent sink for pollutants and heavy metals ${ }^{9,22,23}$. However, the marshlands have faced thirteen years of desiccation from 1990 to $2003^{8,24}$ and this desiccation caused a negative impact on the marshlands' ecosystem and huge changes to environmental variables, which fragmented the historical homogeneity of the marshlands system into several separated systems ${ }^{21}$. The CM's hydrology changed dramatically after 2003, and the area was declared as a protected $\operatorname{area}^{5,6}$ Thus, it is crucial to evaluate heavy metal mobilization and examine whether the $\mathrm{CM}$ could act again as a good sink for heavy metals after the re-flooding and subsequent embankment of the Euphrates River. Water quality of the Marshlands 
after restoration was classified as poor quality ${ }^{1,9}$ Monitoring of heavy metals and studies after reflooding of 2003 have indicated that the Central Marsh has extremely high levels of heavy metals and is considered as a major source of heavy metals to the Shatt Al-Arab in the Basra province compared to other marshes (Haweiza and Hammar marshes) ${ }^{21}$. Although our results agreed with the finding of the previous studies regarding the highlevel concentrations of the heavy metals in the Central Marsh; however, we consider the CM must now be a minor source of heavy metals to the Shatt Al Arab owing to the embankment, which has prevented water from the $\mathrm{CM}$ reaching the Shatt $\mathrm{Al}$ Arab during the survey time of this study. High concentrations of heavy metals in transect 3 (which is located before Chibayish City) and high concentrations in zone D (which is the furthest away zone from the Euphrates River) clearly indicated that the heavy metals are likely to originate from upstream Chibayish City in the West and are then accumulating in the Central Marsh in Zone $\mathrm{D}$ with little chance of passing the embankment. Moreover, our results indicate seasonal variance of heavy metal concentrations in the CM with higher levels in summer. This is unsurprising as water levels are lowest in the summer.

Eutrophication is considered a major problem facing the aquatic environment globally ${ }^{25}$. Water from the Mesopotamian marshlands and Shatt $\mathrm{Al}$ Arab in Basra province are faced with the same problem ${ }^{19,20,25}$. International conventions such as OSPAR (Convention for the Protection of the Marine Environment of the North-East Atlantic) and HELCOM (protect the marine environment of the Baltic Sea from all sources of pollution) have indicated the need to reduce nutrient input to global fresh water and marine environments. Although there is a lack of long-term evidence of performance of the wetlands as a sink for nutrients before going to rivers and marine systems, using wetlands to reduce nutrient concentrations is commonly used globally ${ }^{26}$. Removal rate of total Nitrogen (TN) and Phosphorus (TP) is significantly dependent on Hydrological Loading Rate (HLR), temperature, and concentration in the inlet of the system ${ }^{26}$. Wetlands with controlled HLRs and water pulses are more efficient at removing TP than other wetlands. Nutrient concentrations in the Mesopotamian marshlands after the re-flooding in 2003 were higher than historical records due to sediment organic matter contents that resulted from aquatic plant decomposition and nutrients being liberated from the soil to water as a rehabilitation action after the re-flooding $\left(\mathrm{NO}_{3}, \mathrm{NO}_{2}\right.$, and $\mathrm{PO}_{4}$ concentration were $0.030,0.055$, and $0.22 \mu \mathrm{g} / \mathrm{L}$ respectively in 1988 , and $0.680,49.50,3.60 \mu \mathrm{g} / \mathrm{L}$ respectively in $2006^{19}$. However, other studies suggested that the concentration of nutrients in the marshlands is declining over time after the reflooding, which indicates the important role of the marshlands in removing the extra concentration levels of the nutrients ${ }^{20}$. Our results show no significant variance between nutrients values in the Euphrates River and the CM, which could indicate a limited ability of the marsh to act as a sink to reduce the immediate accumulation of the nutrients. Water levels in the Euphrates River did not exceed the $1.7 \mathrm{~m}$ during the surveys time (Table 10 in the annexes) that means waters of the Euphrates River did not pass the soil embankment and went directly to the CM without outlet or circulation. This could be one of the reasons preventing the CM acting as a sink to remove the nutrients and make its long-term accumulation as the major challenge faced by the $\mathrm{CM}$ under the conditions of the water scarcity in the Euphrates River and establishing the soil embankment. More investigation is needed in order to provide strong evidence of this important role of the $\mathrm{CM}$ and to estimate the removal rate of the nutrients.

Urban runoff, agricultural activities and pollution upstream of Chibayish city ${ }^{19,27}$, evaporation in the summer $^{9,24}$, dams and historical desiccation of the area are likely to be the most important sources of salinity, major ions, heavy metals, and nutrients in the CM. In addition, the existence of the soil embankment has made the CM the terminal site for all Euphrates water that comes from the west of Chibayish city when water depth in the Euphrates is lower than $1.7 \mathrm{~m}$. As a result, over time accumulation could increase the concentration of major ions, salinity, and heavy metals in the CM, and decrease the filtration ability of the marsh and its role as a sink to remove nutrients, salinity, and other pollutants. High concentrations of salinity could have impacts on locals and wildlife. Heavy metals, due to their high concentrations in the water of the CM, could be accumulated in the muscles of fish and milk of water buffalo and that could affect local people's health, as they heavily rely on fish and milk as main sources of food ${ }^{7}$. In addition, high levels of heavy metals could have negative impacts on the wildlife and the ecological function of the marsh, especially the 125-bird species ${ }^{28}$ and the globally endangered soft-shelled turtle Rafetus euphraticus $^{29}$ that use the habitats of the CM. Although the CM is currently facing a critical situation due to water scarcity, it appears that the soil embankment could help keeping waters in the 
$\mathrm{CM}$ and could be viewed as a good temporary solution to help people and wildlife in the CM. However, the negative consequences of this management strategy for major ions accumulations and water salinity have been indicated by our study and could have knock-on effects for more problems in the future. More intensive surveys are required to provide strong evidence for the role of the $\mathrm{CM}$ to remove pollutants, and to evaluate whether the $\mathrm{CM}$ can continue play this important role under the current levels of water scarcity. The question is: how long the site can withstand the current stressors before substantially negative impacts are realised?

\section{Disclosure:}

This work is supported by University of Baghdad, College of Science for Women, Baghdad, Iraq in cooperation with Newcastle University, School of Natural and Environmental Science, Newcastle Upon Tyne, UK.

\section{Supplement file.}

\section{Competing Interest:}

The authors declare that they have no competing interests.

\section{Acknowledgment:}

Thanks go to the University of Technology, Environmental Research Centre in Baghdad (Professor Abdul Hameed Al-Obaidy, Athmar AlMashady, Zhara Zahraw Al-Janabi, Eman Shakir and Ahmad Alwan) for the help in analysis the water samples, and thanks for Dr. Zeyad AlShibaany, University of Technology, Baghdad, Iraq for the help in analysis the $\mathrm{pH}$ values by using MATLAB programme. Thanks for Nature Iraq and the Iraqi Green Climate Organization for providing logistical support during the field surveys in the Central Marshes.

\section{Authors' declaration:}

- Conflicts of Interest: None.

- We hereby confirm that all the Figures and Tables in the manuscript are mine ours. Besides, the Figures and images, which are not mine ours, have been given the permission for republication attached with the manuscript.

- The author has signed an animal welfare statement.

- Ethical Clearance: The project was approved by the local ethical committee in University of Baghdad.

\section{Authors' contributions:}

$\mathrm{N}$ A. Fazaa presented the idea, developed the theory, did the field survey and the statistics, and write the paper. J Dunn provided technical support and did the proofreading. M Whittingham supervised the findings of this work.

\section{References:}

1. Al-Ansari N, Knutsson S, Ali A. Restoring the Garden of Eden. Iraq. J. Earth Sci. Geotech. Eng., 2012; 2(1): 53-88.

2. Partow H. The Mesopotamian marshlands: demise of an ecosystem. U N E P. 2001: 56P.

3. Evans M. Important Bird Areas in the Middle East. Cambridge, UK: BirdLife International; 1994; 2

4. Margaret K. Key Biodiversity Areas of Iraq: Priority Sites for Conservation and Protection Nature Iraq. Nat Areas J. 2019; 39(2): 275-276. Available from: https://doi.org/10.3375/043.039.0214.

5. Alwash A, Gali G, Fazaa NA, and Sopelsa, A. The Mesopotamian Marshlands National Park Planning Process. Conference of College of Science. University of Baghdad. 2009.

6. F. Pearce. Garden of Eden to be protected as Iraqi national park. New Sci. 2013; 219 (2928): 11 pages. Available from: https://doi.org/10.1016/S02624079(13)61910-7

7. Fazaa NA, Dunn JC, Whittingham MJ. Evaluation of the Ecosystem Services of the Central Marsh in Southern Iraq. Baghdad Sci J. 2018; 15(4):369-380. Available from: DOI: http://dx.doi.org/10.21123/bsj.2018.15.4.0369.

8. Richardson C J, Hussain NA. Restoring the Garden of Eden: An Ecological Assessment of the Marshes of Iraq. BioScience. 2006; 56(6): 477.

9. Nature Iraq. New Eden Master Plan for Integrated Water Resources Management in the Marshlands Area. Book 4. 2006. Available from: WWW. Nature Iraq.org.

10. Al-Ansari N, Sven K. Toward Prudent management of Water Resources in Iraq. JASER. 2011; 1(2011): 53-67.

11. Hasan M., Moody A, Benninger L. et al. How war, drought, and dam management impact water supply in the Tigris and Euphrates Rivers. Ambio. 2019; 48(3): 264 - 279 https://doi.org/10.1007/s13280-0181073-4.

12. Al-Ansari N, Adamo N, Sisskian V K, Knutsson S, Laue J. Water Resources of the Euphrates River Catchment. J Earth Sci Geotech Eng. 2018; 8(3):1-20.

13. Al-Ansari N, Al-Jawad S, Adamo N, Sisskin V K, Laue J, Knutsson S. Water Quality within the Tigris and Euphrates Catchments. J Earth Sci Geotech Eng. 2018; 8(3):95-121.

14. Al- Ansari N, Adamo N, Knutsson S, Laue J. Geopolitics of the Tigris and Euphrates Basins. J Earth Sci Geotech Eng. 2018; 8(3):187-222.

15. Al-Ansari N. Management of Water Resources in Iraq: Perspectives and Prognoses. Engineering. 2013;5: 667-684. Available from: http://dx.doi.org/10.4236/eng.2013.58080

16. Sama A, Ali D, Hamid A S. Mesopotamian Marshlands: Salinization Problem. J. Environ Prot. 2012; 3(10): 1295-1301. 
17. Andrew D Eaton, Standard methods for the examination of water and wastewater. Am Publ Health Assoc 2005; $21^{\text {st }}$ ed

18. Al Maarofi S. Ecological Assessment of Re-flooded Mesopotamian Marshes (Iraq) UW Space: Ph D Theses: University of Waterloo; 2015. Available from: http://hdl.handle.net/10012/10055.

19. Al-Saad H T, Al-Hello M A, Al-Taein S M, Douabul A A Z. Water quality of the Iraqi southern marshes. Mesopot. J Mar Sci. 2010; 25 (2): 188 - 204.

20. Douabul A A Z, Al-Mudhafer N A, Alhello A A, AlSaad H T, Al-Maarofi S S. Restoration versus Reflooding: Mesopotamia Marshlands. Hydrol Curr Res. 2012; 3(5): 140.

21. Al-Maarofi S S, Alhello A Z, Fawzi NA, Douabul A A Z, Al-Saad H T. (2013) Desiccation versus reflooding: heavy metals mobilization-Part 1. J Environ Prot. 2013; 4(08): 27-36.

22. Fikrat M H, Maysoon M S, Jasim M S. A Study of Physicochemical Parameters and Nine Heavy Metals in the Euphrates River, J Chem. 2009; 7 (3):685-692.

23. Richardson C J, Reiss P, Hussain N A, Alwash A J, Pool D J. The restoration potential of the Mesopotamian marshes of Iraq. Science. 2005; 307(5713):1307-1311.

24. Adil A H, Chuanmin H. MODIS Observations of Human-Induced Changes in the Mesopotamian Marshes in Iraq. Wetlands 2015; 35(1): 31-40.
25. Abdullah S A, Abdullah, A H J, Ankush, M A. Assessment of Water Quality in the Euphrates River, Southern Iraq. Iraqi J Agric Sci.2019, 1029:50(1):221-228.

26. Land M, Granéli W, Grimvall A, Hoffmann C C, Mitsch W J, Tonderski K S, et al. How effective are created or restored freshwater wetlands for nitrogen and phosphorus removal? A systematic review protocol, Environ. Evid. 2016; 5(9): 1-26.

27. Fikrat M. Hassana , Abdul Hameed M.J. Al-Obaidyb, Ali O. Shaawiatc. Evaluation of Al-Shamiyah River water quality using the Canadian Council of Ministries of the Environment (CCME) water quality index and factor analysis. Desal Wat Treat. 2018,116 342-348. doi:10.5004/dwt.2018.22553.

28. Fazaa, N A, Dunn J C, Whittingham M J. Distributions and community composition of birds in Iraq's Central Marsh. Int j biodivers. 2017: 1-18. Article ID 4198690. doi:10.1155/2017/4198690.

29. Fazaa N A, Dunn J C, Whittingham M J. Status of Euphrates soft-shelled turtle Rafetus euphraticus in the Iraqi Central Marsh. International Conference on Latest Trends in Food, Biological \& Ecological Sciences (ICLTFBE'15). Dubai (UAE): Oct. 2015: 44-49 http://iaast.org/upload/7172A1015063.pdf.

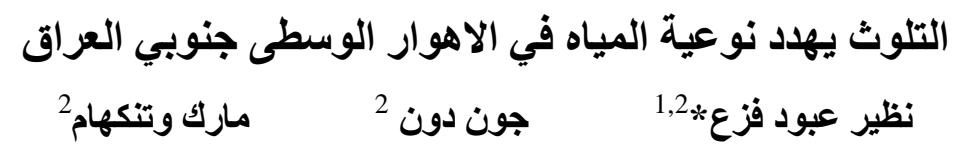

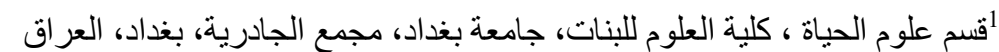

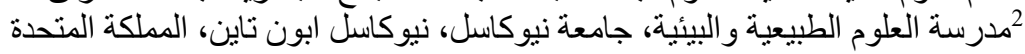

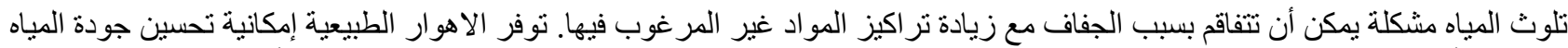

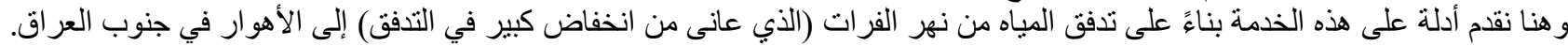

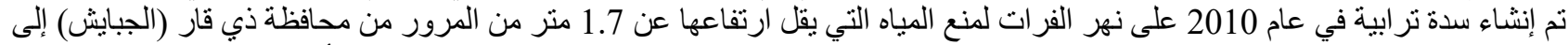

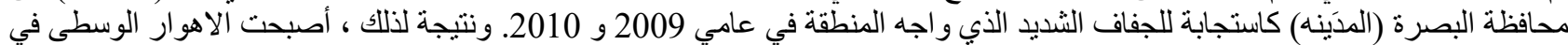

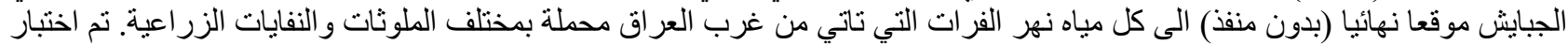

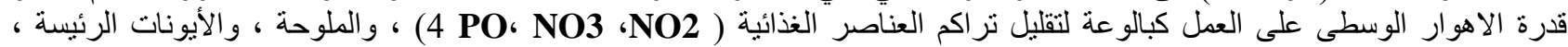

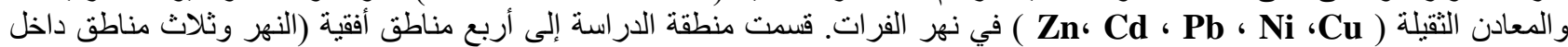
الهور) و أجريت ثمانية مسوحات ميدانية من تشرين الثاني (transect line methodology)

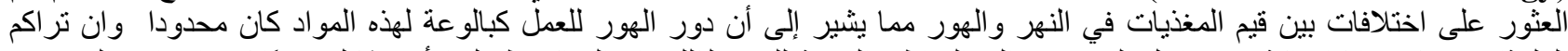

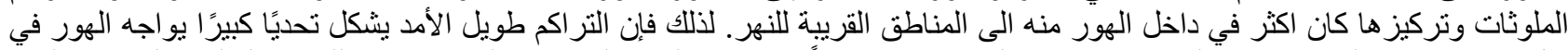

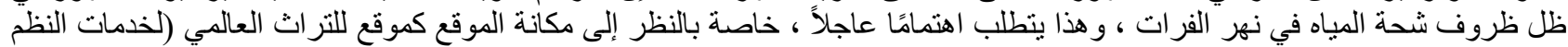

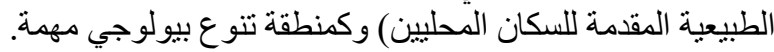

$$
\text { الكلمات المفتاحية: الاهو ار المركزية، اهو ار بلاد وادي الر افدين، جودة المياه، ملوحة المياه. }
$$

